\title{
Entrepreneurial Orientation Level in Mexican SMEs
}

\author{
Gonzalo Maldonado-Guzmán ${ }^{1}$, Gabriela Citlalli López-Torres ${ }^{1} \&$ Sandra Yesenia Pinzón Castro ${ }^{1}$ \\ ${ }^{1}$ Centre of Economic and Administrative Sciences, Universidad Autónoma de Aguascalientes, Aguascalientes, \\ México \\ Correspondence: Gabriela Citlalli López-Torres, Centre of Economic and Administrative Sciences, Universidad \\ Autónoma de Aguascalientes, Aguascalientes, 20131, México. E-mail: gclopto@gmail.com
}

Received: February 17, 2016 Accepted: March 7, 2016 Online Published: April 27, 2016

doi:10.5539/jms.v6n2p89 URL: http://dx.doi.org/10.5539/jms.v6n2p89

\begin{abstract}
In the current literature, there is an important debate about the nature and way of measuring the entrepreneurial orientation level in companies. Some researchers regard this as a one-dimension construct, whereas others view this as a multi-dimensional construct that can vary in an independent manner. Similarly, others consider that the right scale to measure entrepreneurial orientation is through three dimensions instead of five as some propose. Therefore, the objective of this investigation is to analyze the level of entrepreneurial orientation of small and medium-size enterprises (SMEs) by using three dimensions: proactivity, risk taking and innovation in a sample of 318 companies in Aguascalientes region, Mexico. The results obtained show that proactivity, risk taking and innovation have significant positive effects on business orientation of small and medium-size enterprises.
\end{abstract}

Keywords: entrepreneurial orientation, small and medium enterprises

\section{Introduction}

Entrepreneurial orientation has been analyzed and discussed in several theoretical and empirical studies in entrepreneurial literature by different scholars, researchers and professionals of business and management sciences for over three decades (Covin \& Wales, 2012). Moreover, empirical studies have been implemented in numerous activities of entrepreneurism in organizations, which usually consider the entrepreneurial orientation as an important proactive way of decision-making that promotes all activities related directly and indirectly to entrepreneurism that companies have adopted and implemented (Lumpkin \& Dess, 1996).

In this regard, entrepreneurial orientation is usually considered from an organizational point of view, as a conservative concept that can measure only a small part of entrepreneurism in companies, especially in small and medium-size (SMEs) (Covin \& Slevin, 1998; Barringer \& Bluedorn, 1999). It can also be considered as a multi-dimensional concept that measures almost all entrepreneurism in companies (Lumpkin \& Dess, 1996; Antoncic \& Hisrich, 2003). Similarly, different studies about entrepreneurial orientation, which are published in the current literature, have mostly been applied in several orientations that organizations have adopted in the implementation of entrepreneurial activities both in young and older companies, as well as in SMEs and large public or private companies (Covin \& Wales, 2012).

Moreover, several researchers, scholars and professionals of business and management sciences, and entrepreneurism have different opinions about the conceptualization of latent constructs and if they have to be measured directly or indirectly (Lumpkin \& Dess, 1996; Covin, Green, \& Slevin, 2006). However, investigations like the one presented by George (2011) establish that many researchers and scholars from the area of entrepreneurial orientation have already determined a measurement model that can be used, implicitly or explicitly, which is the reason why they use an indirect measurement scale rather than a direct one.

In this context, there are many published empirical studies indicating that entrepreneurial orientation is commonly considered as an indirect construct with many variables measuring different components or dimensions (Diamantopoulos \& Winklhofer, 2001; Jarvis, MacKenzie, \& Podsakoff, 2003; Howell, Breivik, \& Wilcox, 2007; Coltman, Devinney, Midgley, \& Vanaik, 2008). They often based their scale in the one proposed by Lumpkin \& Dess (1996) and Miller (1983) and establish that entrepreneurial orientation can be measured through three factors or dimensions: proactivity, risk taking and innovation, whereas entrepreneurial orientation is considered as an indirect construct instead of a direct one.

Thus, the main contribution of this empirical investigation is the analysis of the level of entrepreneurial 
orientation in SMEs operating in an emerging country, like Mexico. The rest of the paper has been organized as follows; the second section presents a review of the theoretical framework, previous empirical researches and formulation of the research hypotheses. The third section describes the research methodology, sample and the variables used. The fourth section analyzes the results obtained, while the final section illustrates the main conclusions and discussion of this empirical research.

\section{Literature Review}

The construct of entrepreneurial orientation was first analyzed and presented in the literature by Mintzberg (1973) and Khandwalla (1977) who considered that entrepreneurial companies normally take more risks than those that have not adopted this orientation into their organization. Additionally, companies are usually more proactive in the development of new business opportunities provided in the market in which they participate. Nonetheless, entrepreneurial orientation was given a higher emphasis in Miller's research (1983), who did not only define more precisely this construct but he presents the conclusion that entrepreneurial orientation is a multi-dimensional concept, which can be easily measured through three essential factors or dimensions, present in every company: proactivity, risk taking and innovation.

In a previous research, Miller \& Friesen (1982) used five items closely related to risk taking and innovation in order to measure and differentiate entrepreneurial enterprises from conservative ones. On the other hand, Morris \& Paul (1987) using as a basis the studies done by Khandwalla (1977) and Ginsberg (1985), proposed a 13 items - scale to measure and to examine the relationship between marketing and entrepreneurism. Alternatively, Covin \& Slevin (1989), also using as basis the research of Khandwalla (1977) and Miller \& Friesen (1982), proposed a scale to measure the entrepreneurial orientation construct with three items for each factor of the those identified by Miller (1983): proactivity, risk taking and innovation.

Covin \& Slevin (1989) while developing such scale also concluded that those three dimensions to measure entrepreneurial orientation, proactivity, risk taking and innovation, can work together as a single dimension, and the possible variations that this scale can have are the ones commonly used in the literature to measure entrepreneurial orientation. In summary, this scale appears to be the most used in the current literature by a great deal of researchers, scholars and professionals of business sciences and entrepreneurism (George, 2011). On one hand, the scale considers specifically the dimensions of the measurement of the entrepreneurial orientation (Zahra, 1993; Lumpkin \& Dess, 1996; Knight, 1997), abut also incorporates the existing interdependence among such dimensions (Lumpkin \& Dess, 1996; Dess, Lumpkin, \& McGee, 1999).

Thus, research that have considered the uni-dimensionality of the entrepreneurial measuring usually have been focused on the use of the addition resulted from a series of items that are representative of such entrepreneurial orientation construct that companies have adopted or implemented when compared to investigations considering entrepreneurial orientation as multi-dimensional, measured through various sub-dimensions (Lumpkin \& Dess, 1996). As a result, the use of this multi-dimensional scale to measure entrepreneurial orientation is distinctively relevant in the current literature, for instance, Kreiser, Marino, \& Weaver (2002) defined that 18 out of 19 empirical studies that analyzed entrepreneurial orientation used a similar scale for its measurement.

Another issue of great debate in the current literature is the one between the quantity of factors or dimensions that must be considered to measure entrepreneurial orientation in companies and whether these dimensions or factors have to be independent from each other (George, 2011). This debate was started by Lumpkin \& Dess (1996) when they reached the conclusion that to addition to the three factors or dimensions commonly used, it could be possible to add two more: autonomy and competitive aggressiveness. Such dimensions could covariate among them and could be independent from each other (Covin \& Slevin, 1989). Also, other empirical studies published in the current literature analyzed the relationship between factors or dimensions and concluded that they can vary independently from each other (Stetz, Howell, Stewart, Blair, \& Fottler, 2000; Kreiser et al., 2002; Richard, Barnett, Dwyer, \& Chadwick, 2004).

In this regard, the study published by Miller \& Friesen (1982) was the first one bringing an insight about the level of entrepreneurial orientation that it could be measured trough three dimensions that generally took place by means of a group of a specific organizational behaviour. In fact, normally entrepreneurial companies carry out innovation activities that have a high level of risk in their product-market strategies. Correspondingly, Miller (1983) considered that entrepreneurial companies have proactivity attributes for innovation that happen in product-market activities and that often have a high level of risk when they are the first ones in the introduction of innovative products or services instead of their competitors. That is why Miller (1983) reached the conclusion that entrepreneurial orientation is a multi-dimensional construct that can be measured by means of three dimensions: proactivity, risk taking and innovation. 
Additionally, Miller (1983) considered that entrepreneurial orientation is a construct made by three dimensions or factors that can positively covariate among themselves depending on how it is adopted and implemented by organizations, especially SMEs. Also, from his research, he concluded that there is a high relationship and variance among these three dimensions and in the absence of covariance between proactivity, risk taking and innovation, it would be very difficult and complicated to define if enterprises have an entrepreneurial orientation or not.

Likewise, Lumpkin, \& Dess (1996) suggested that entrepreneurial orientation does not only include processes, practices and decision making of those activities related to the introduction of new innovations into the enterprises. But it also includes the intention and actions implemented by their main competitors in a dynamic market process that offers alternative entering opportunities to new competitors. Consequently, Dess \& Lumpkin (2001) concluded that entrepreneurial orientation is an organizational level and a process of strategic adoption by which the dimensionality of the construct is known as a priori, despite of the circumstances and the environment that surround the companies that adopt and implement it.

In this regard, in order to increase the number of factors or dimensions that distinguish and allow to act on the entrepreneurial orientation, Lumpkin \& Dess (1996) considered that this can be measured through proactivity, risk taking, innovation, competitive aggressiveness and autonomy. Mainly because these five dimensions apart from being mutually independent, together these also allow measuring easily the level of entrepreneurial orientation that companies have. However, different researchers, scholars and professionals from the area of entrepreneurism do not agree totally in the use of these five dimensions since they consider that it is better to use three dimensions because proactivity, risk taking and innovation allow measuring the essence of entrepreneurial orientation of organizations (Miller, 1983; Covin \& Slevin, 1989; George, 2011; Covin \& Wales, 2012).

The theoretical and empirical contributions, from the current literature, from Miller (1983), Covin \& Slevin (1989) and Lumpkin \& Dess (1996), and from other important number of researchers, scholars and professionals of management sciences and the area of entrepreneurism, have analyzed and discussed the most adequate amount of dimensions or factors to measure the entrepreneurial orientation. They have arrived to the conclusion that the most adequate way to measure it is through three factors -proactivity, risk taking and innovation- because through them it is possible to measure this phenomenon (Kreiser et al., 2002; Covin et al., 2006; George, 2011; Covin \& Wales, 2012). Therefore, considering the information presented previously, at this moment it is possible to formulate the following hypotheses:

\section{H1: The higher level of proactivity, the higher level of entrepreneurial orientation}

\section{H2: The higher level of risk taking, the higher level of entrepreneurial orientation}

\section{H3: The higher level of innovation, the higher level of entrepreneurial orientation}

\section{Method}

In order to test the hypotheses presented in the theoretical framework about the measurement of entrepreneurial orientation, an empirical study was carried out in 318 SMEs in Aguascalientes region in Mexico by taking into account the directory of the Business Information System in Mexico (SIEM). Aguascalientes region has 5,194 registered companies, in June 2013. For practical purposes, only companies with 5 to 250 employees were considered. Therefore, the population was reduced to 1,261 enterprises. Random sampling was used and selected considering a reliability level of $96 \%$ and a sampling error of $\pm 4.5 \%$, which gives a total of 368 enterprises. Equally, an instrument for data collection was designed and it had to be completed by the SMEs managers and/or owners. The questionnaire was carried out as a personal interview to the 400 selected companies. From these, 318 were validated, which give a response rate of $87 \%$, the data collection process went from August 2013 to October 2013.

In order to measure entrepreneurial orientation, a scale proposed by Miller (1983) with adaptations from Covin \& Slevin (1991) and Dess \& Lumpkin (2001) was used in this investigation. They established that this type of orientation can be measured with three dimensions or factors: proactivity, risk taking and innovation. Each one of them was measured by means of a six-item scale. Additionally, all the items of the three dimensions were measured by means of a five-point Likert scale; where $1=$ Totally agree and $5=$ Totally disagree, as limits.

In order to assess the reliability and the validity of the measurement scales; we carried out a Confirmatory Factor Analysis (CFA) using the maximum likelihood method in the EQS 6.1 software (Bentler, 2005; Brown, 2006; Byrne, 2006). The reliability of measures was assessed with Cronbach's alpha and the Composed Reliability Index (CRI) (Bagozzi \& Yi, 1988). The CFA results are presented in Table 1 and reveal that the measurement model provides a good fit to the data according to the statistical adjustment $\left(S-B X^{2}=155.704 ; d f=87 ; p=0.000\right.$; 
$N F I=0.905 ; N N F I=0.946 ; C F I=0.955 ;$ and $R M S E A=0.050$ ). As evidence of convergent validity, the results of the CFA indicate that all items of the related factors are significant $(\mathrm{p}<0.001)$, the size of all standardized factor loadings are above 0.70 (Bagozzi \& Yi, 1988) and the average variance extracted (AVE) for each pair of constructs is greater than 0.5 as recommended by Fornell \& Larcker (1981). All the measures showed a satisfactory level of reliability, exceeding the recommended level of 0.7 for Cronbach's alpha, and the CRI provided evidence about reliability and justifies the scales' internal reliability (Hair et al., 1995).

Table 1. Internal consistency and convergent validity of the theoretical model

\begin{tabular}{|c|c|c|c|c|c|c|}
\hline Variable & Indicator & Factorial load & Robust t value & $\begin{array}{l}\text { Cronbach's } \\
\text { alpha }\end{array}$ & CFA & AVE \\
\hline \multirow{5}{*}{ Proactivity } & PR1 & $0.779 * * *$ & $1.000^{\mathrm{a}}$ & \multirow{5}{*}{0.842} & \multirow{5}{*}{0.846} & \multirow{5}{*}{0.526} \\
\hline & PR2 & $0.626 * * *$ & 11.280 & & & \\
\hline & PR4 & $0.718 * * *$ & 11.454 & & & \\
\hline & PR5 & $0.743 * * *$ & 11.569 & & & \\
\hline & PR6 & $0.749 * * *$ & 12.226 & & & \\
\hline \multirow{5}{*}{ Risk taking } & TR1 & $0.765^{* * *}$ & $1.000^{\mathrm{a}}$ & \multirow{5}{*}{0.852} & \multirow{5}{*}{0.856} & \multirow{5}{*}{0.545} \\
\hline & TR2 & $0.664 * * *$ & 8.461 & & & \\
\hline & TR4 & $0.787 * * *$ & 9.349 & & & \\
\hline & TR5 & $0.793 * * *$ & 9.997 & & & \\
\hline & TR6 & $0.673 * * *$ & 9.820 & & & \\
\hline \multirow{5}{*}{ Innovation } & IN1 & $0.727 * * *$ & $1.000^{\mathrm{a}}$ & \multirow{5}{*}{0.861} & \multirow{5}{*}{0.863} & \multirow{5}{*}{0.560} \\
\hline & IN2 & $0.640 * * *$ & 12.997 & & & \\
\hline & IN3 & $0.803 * * *$ & 13.281 & & & \\
\hline & IN4 & $0.751 * * *$ & 11.750 & & & \\
\hline & IN5 & $0.808 * * *$ & 15.397 & & & \\
\hline$S-B X^{2}(\mathrm{df}=$ & $\mathrm{p}<0.000$ & $\mathrm{NFI}=0.905$ & $\mathrm{NNFI}=0.946$ & $\mathrm{CFI}=0.955$ & $\mathrm{EA}=0.050$ & \\
\hline
\end{tabular}

Table 2 shows the discriminant validity through two different contrasts. First, considering a $95 \%$ of reliability interval, none of the individual factors contains the value 1.0 (Anderson \& Gerbing, 1988). Second, the variance extracted between each pair of constructs in the model is higher than the corresponding AVE (Fornell \& Larcker, 1981). These results conclude that this work reveals sufficient evidence about reliability, and convergent and discriminant validity of the theoretical model.

Table 2. Discriminant validity of the theoretical framework

\begin{tabular}{llll}
\hline Variables & Proactivity & Risk taking & Innovation \\
\hline Proactivity & $\mathbf{0 . 5 2 6}$ & 0.116 & 0.177 \\
Risk taking & $0.242-0.438$ & $\mathbf{0 . 5 4 5}$ & 0.174 \\
Innovation & $0.313-0.529$ & $0.289-0.545$ & $\mathbf{0 . 5 6 0}$ \\
\hline
\end{tabular}

The diagonal represents the Index of Extracted Variance (IVE) whereas above the diagonal the part of the variance is shown (the correlation AL CUADRO). Under the diagonal it can be seen the estimation of the correlation of the factors with a reliability interval of $95 \%$.

\section{Results}

In order to test the hypotheses presented from the theoretical model, a model of structural equations with software EQS 6.1 by means of CFA was applied (Bentler, 2005; Byrne, 2006; Brown, 2006). The nomological validity of the theoretical model was examined through the Chi test square, which compared to the results obtained between the theoretical model and the measurement model indicate that the differences between both models are not significant and can offer an explanation of the relationships observed among the latent constructs (Anderson \& Gerbing, 1988; Hatcher, 1994). Table 3 demonstrates the results in a more detailed manner. 
Table 3. Results of the model - structural equations

\begin{tabular}{llll}
\hline Hypothesis & Structural Relation & $\begin{array}{l}\text { Standardized } \\
\text { Coefficient }\end{array}$ & $\begin{array}{c}\text { Robust t } \\
\text { value }\end{array}$ \\
\hline $\begin{array}{l}\mathbf{H}_{1}: \text { The higher level of proactivity, the higher } \\
\text { level of entrepreneurial orientation. }\end{array}$ & Proactive $\rightarrow$ Entrepreneurial O. & $0.308^{* * *}$ & 9.401 \\
\hline $\begin{array}{l}\mathbf{H}_{2}: \text { The higher level of risk taking, the higher } \\
\text { level of entrepreneurial orientation. }\end{array}$ & Risk Taking $\rightarrow \quad$ Entrepreneurial O. & $0.325^{* * *}$ & 11.632 \\
\hline $\begin{array}{l}\mathbf{H}_{3}: \text { The higher level of innovation, the higher } \\
\text { level of entrepreneurial orientation. }\end{array}$ & Innovation $\rightarrow \quad$ Entrepreneurial O. & $0.347^{* * *}$ & 13.356 \\
\hline$S-B X^{2}(\mathrm{df}=83)=148.545 ; \quad \mathrm{p}<0.000 ; \quad \mathrm{NFI}=0.909 ; \quad \mathrm{NNFI}=0.946 ; \quad \mathrm{CFI}=0.957 ;$ & $\mathrm{RMSEA}=0.050$ \\
\hline \begin{tabular}{l} 
Note. $* * *=\mathrm{P}<0.001$. \\
\hline
\end{tabular}
\end{tabular}

Table 3 shows the results obtained from the implementation of the structural equations model. Moreover, regarding the hypothesis $\mathbf{H}_{1}$, the results obtained, $\beta=0.308, \mathrm{p}<0.001$, indicate that proactivity has significant positive effects in the entrepreneurial orientation of SMEs in Mexico. Regarding the hypothesis $\mathbf{H}_{\mathbf{2}}$ the results obtained $\beta=0.325, \mathrm{p}<0.001$, indicate that risk taking has a significant positive effect in the entrepreneurial orientation of SMEs. Regarding the hypothesis $\mathbf{H}_{3}$ the results obtained, $\beta=0.347, \mathrm{p}<0.001$, indicate that innovation also has a positive and significant impact in the entrepreneurial orientation of SMEs in Mexico. Therefore, it is possible to conclude that entrepreneurial orientation, measured through three dimensions (proactivity, risk taking and innovation) is a good indicator to measure the entrepreneurial orientation of SMEs.

\section{Discussion}

Based on the results obtained in this empirical research, it is possible to conclude that proactivity, risk taking and innovation have a strong influence in the level of entrepreneurial orientation adopted and implemented by SMEs in Mexico. It can also be concluded that in order for organizations to increase a certain level of entrepreneurial orientation director; the organisation have to implement additional proactive activities in everyday business strategies, so that they can get ahead of the market needs and requirements in which they participate. Furthermore; the organisation has to make necessary adjustments and changes to their products and services in line with the preferences and needs of current and future consumers.

Similarly, managers should incorporate all activities that have a high level of risk, for example innovation activities, but having the necessary information about the market, clients and consumers in order to reduce risks and improve decision-making. Moreover, managers of SMEs have to incorporate innovation initiatives in the everyday activities, in such a manner that they carry out adaptations or changes to products and services that their organization provides; in order to adapt and personalize them with the obkectives of fulfilling their consumers' preferences and needs.

Besides, the measurement of entrepreneurial orientation can be probably easier through the these three dimensions: proactivity, risk taking and innovation, these show that such scale proposed by Miller (1983) is an adequate scale to measure entrepreneurial orientation. Even though Lumpkin \& Dess (1996) claim that entrepreneurial orientation is probably easier to measure through five dimensions: proactivity, decision-making, innovation, aggressive competitiveness and autonomy. The results obtained in this empirical research can show that there is no need to incorporate additional dimensions to the scale developed by Miller (1983).

Also, entrepreneurial orientation can be viewed as a reflective construct rather than formative since results obtained in this empirical research provide empirical evidence that sustain such insight. This ratifies the results obtained by different researchers, scholars and professionals in the field of entrepreneurism in regards to the idea that entrepreneurial orientation can be considered more as reflective construct than formative. These results increase the level of analysis and discussion of this topic in the literature, mainly because the results obtained tip the scales without disregarding in any way that any additional studies can show the opposite, as it happens now in the current literature.

In this sense, in most empirical studies published in the current literature, the scale proposed by Miller (1983) has traditionally been considered to measure entrepreneurial orientation by three dimensions. Similarly, this construct has been considered more formative than reflective by an important number of researchers and scholars. Even when there are published studies that have obtained theoretical and empirical evidence, which prove that the measurement of entrepreneurial orientation is better when adding to dimensions to the scale proposed by Miller (1983), apart from considering this construct more reflective than formative it is vital to carry out more research, both theoretical and empirical in order to clarify these current questions. 
Additionally, this research has different important limitations to consider. The first limitation is related to the use of measuring scales for entrepreneurial orientation, mainly because there were three dimensions used. Future researches will need to incorporate the use of different scales to verify the results obtained. The second limitation is the process of gathering information because only a small part of information about entrepreneurial orientation was considered especially with qualitative variables. Further research will require incorporating quantitative variable to prove if same results are obtained.

The third limitation is about the measurement of variables with the scale used because six items were used for each of the three factors to measure entrepreneurial orientation. It will be useful for future research to use alternative items or an additional number of items to measure entrepreneurial orientation. A fourth limitation is that the interviews were applied only to SMEs managers and/or owners so the results obtained can be different if another population are examined, such as, clients and consumers. Future investigations should incorporate it in order to verify the results obtained.

The last limitation is the sample that only incorporates SMEs from five to twenty employees operating Aguascalientes region, Mexico. Future research will need to consider enterprises with less than five employees as they represent more than $60 \%$ of the population in order to verify the results obtained. Finally, it is wise to go beyond the result presented in this research to analyze and discuss more deeply the following questions: What effects would be obtained in SMEs if a quantitative scale were used to measure entrepreneurial orientation? What results would be obtained in SMEs if another dimension were used to measure entrepreneurial orientation? These and other questions that may arise could be answered in further investigations.

\section{References}

Anderson, J., \& Gerbing, D. (1988). Structural equation modeling in practice: a review and recommended two-step approach. Psychological Bulletin, 13, 411-423. http://dx.doi.org/10.1037/0033-2909.103.3.411

Antoncic, B., \& Hisrich, R. D. (2003). Clarifying the entrepreneurship concept. Journal of Small Business and Enterprise Development, 10, 1-24. http://dx.doi.org/10.1108/14626000310461187

Bagozzi, R. P., \& Yi, Y. (1988). On the evaluation of structural equation models. Journal of the Academy of Marketing Science, 16(1), 74-94. http://dx.doi.org/10.1007/BF02723327

Barringer, B. R., \& Bluedorn, A. C. (1999). The relationship between corporate entrepreneurship and strategic $\begin{array}{lllll}\text { management. } \quad \text { Strategic } & \text { Management }\end{array}$ http://dx.doi.org/10.1002/(SICI)1097-0266(199905)20:5\%3C421::AID-SMJ30\%3E3.0.CO;2-O

Bentler, P. M. (2005). EQS 6 Structural Equations Program Manual. Encino, CA: Multivariate Software.

Brown, T. (2006). Confirmatory Factor Analysis for Applied Research. New York, NY: The Guilford Press.

Byrne, B. (2006). Structural Equation Modeling with EQS, basic concepts, applications, and programming (2nd ed.). London: LEA Publishers.

Coltman, T., Devinney, T. M., Midgley, D. F., \& Venaik, S. (2008). Formative versus reflective measurement models: Two applications of formative measurement. Journal of Business Research, 61, 1250-1262. http://dx.doi.org/10.1016/j.jbusres.2008.01.013

Covin, J. G., \& Slevin, D. (1989). Strategic management of small firms in hostile and benign environments. Strategic Management Journal, 10, 75-87. http://dx.doi.org/10.1002/smj.4250100107

Covin, J. G., \& Slevin, D. (1991). A conceptual model of entrepreneurship as firm behavior. Entrepreneurship Theory and Practice, 16(1), 7-24.

Covin, J. G., \& Slevin, D. P. (1998). The influence of organizational structure on the utility of an entrepreneurial top management style. Journal of Management Studies, 25(3), 217-234. http://dx.doi.org/10.1111/j.1467-6486.1988.tb00033.x

Covin, J. G., \& Wales, W. J. (2012). The measurement of entrepreneurial orientation. Entrepreneurship Theory and Practice, 7, 677-702. http://dx.doi.org/10.1111/j.1540-6520.2010.00432.x

Covin, J. G., Green, K. M., \& Slevin, D. P. (2006). Strategic process effects of the entrepreneurial orientation-sales growth rate relationship. Entrepreneurship Theory and Practice, 30, 57-81. http://dx.doi.org/10.1111/j.1540-6520.2006.00110.x

Dess, G. G., \& Lumpkin, G. T. (2001). Emerging issues in strategy process research. In M. A. Hitt, R. E. Freeman, \& J. S. Harrison (Eds.), Blackwell Handbook of Strategic Management. Malden, MA: Blackwell Publishers Inc. 
Dess, G. G., Lumpkin, G. T., \& McGee, J. E. (1999). Linking corporate entrepreneurship to strategy, structure and process: Suggested research directions. Entrepreneurship Theory and Practice, 23, 85-102.

Diamantopoulos, A., \& Winklhofer, H. M. (2001). Index construction with formative indicators: An alternative to scale development. Journal of Marketing Research, 38, 269-277. http://dx.doi.org/10.1509/jmkr.38.2.269.18845

Fornell, C., \& Larcker, D. (1981). Evaluating structural equation models with unobservable variables and measurement error. Journal of Marketing Research, 18, 39-50. http://dx.doi.org/10.2307/3151312

George, B. A. (2011). Entrepreneurial orientation: A theoretical and empirical examinations of the consequences of differing construct representation. Journal of Management Studies, 48(6), 1291-1313. http://dx.doi.org/10.1111/j.1467-6486.2010.01004.x

Ginsberg, A. (1985). Measuring changes in entrepreneurial orientation following industry deregulation: The development of a diagnostic instrument. Proceedings, International Council of Small Business, Montreal, CA.

Hair, J. F., Anderson, R. E., Tatham, R. L., \& Black, W. C. (1995). Multivariate Data Analysis with Readings. New York, NY: Prentice-Hall.

Hatcher, L. (1994). A Step by Step Approach to Using the SAS System for Factor Analysis and Structural Equation Modeling. Cary, NC: SAS Institute Inc.

Howell, R. D., Breivik, E., \& Wilcox, J. B. (2007). Reconsidering formative measurement. Psychological Methods, 12, 205-218. http://dx.doi.org/10.1037/1082-989X.12.2.205

Jarvis, C. B., MacKenzie, S. B., \& Podsakoff, P. M. (2003). A critical review of construct indicators and measurement model misspecification in marketing and consumer research. Journal of Consumer Research, 30, 199-218. http://dx.doi.org/10.1086/376806

Khandwalla, P. N. (1977). Some top management styles, their context and performance. Organization \& Administrative Sciences, 7, 21-51.

Knight, G. A. (1997). Cross-cultural reliability and validity of a scale to measure firm entrepreneurial orientation. Journal of Business Venturing, 12, 213-225. http://dx.doi.org/10.1016/S0883-9026(96)00065-1

Kreiser, P. M., Marino, L. D., \& Weaver, K. M. (2002). Assessing the psychometric properties of the entrepreneurial orientation scale: A multi-country analysis. Entrepreneurship Theory and Practice, 26, 71-94.

Lumpkin, G. T., \& Dess, G. G. (1996). Clarifying the entrepreneurial orientation construct and linking it to $\begin{array}{llll}\text { performance. Academy } & \text { 135-172. }\end{array}$ http://dx.doi.org/10.5465/AMR.1996.9602161568

Lumpkin, G. T., \& Dess, G. G. (2001). Linking two dimensions of entrepreneurial orientation to firm performance: The moderating role of environment industry life cycle. Journal of Business Venturing, 16, 429-451. http://dx.doi.org/10.1016/S0883-9026(00)00048-3

Miller, D. (1983). The correlates of entrepreneurship in three types of firms. Management Science, 29, 770-791. http://dx.doi.org/10.1287/mnsc.29.7.770

Miller, D., \& Friesen, P. H. (1982). Innovation in conservative and entrepreneurial firms: Two models of strategic momentum. Strategic Management Journal, 3, 1-25. http://dx.doi.org/10.1002/smj.4250030102

Mintzberg, H. (1973). Strategy-making in three modes. California Management Review, 16(2), 44-53. http://dx.doi.org/10.2307/41164491

Morris, M. H., \& Paul, G. W. (1987). The relationship between entrepreneurship and marketing in established firms. Journal of Business Venturing, 2(2), 247-259. http://dx.doi.org/10.1016/0883-9026(87)90012-7

Nunnally, J. C., \& Bernstein, I. H. (1994). Psychometric Theory (3rd ed.). New York, NY: McGraw-Hill.

Richard, O. C., Barnett, T., Dwyer, S., \& Chadwick, K. (2004). Cultural diversity in management, firm performance and the moderating role of entrepreneurial orientation dimensions. Academy of Management Journal, 47, 255-266. http://dx.doi.org/10.2307/20159576

Stetz, P. E., Howell, R., Stewart, A., Blair, J. D., \& Fottler, M. D. (2000). Multidimensionality of entrepreneurial firm-level processes: Do the dimensions covary? In E. Autio, C. G. Brush, W. D. Bygrave, S. Manigart, P. D. Reynolds, H. J. Sapienza, \& K. G. Shaver (Eds.), Frontiers of Entrepreneurship Research. Wellesley, MA: 
Babson College.

Zahra, S. A. (1993). Environment, corporate entrepreneurship and financial performance: A taxonomic approach. Journal of Business Venturing, 8, 319-340. http://dx.doi.org/10.1016/0883-9026(93)90003-N

\section{Copyrights}

Copyright for this article is retained by the author(s), with first publication rights granted to the journal.

This is an open-access article distributed under the terms and conditions of the Creative Commons Attribution license (http://creativecommons.org/licenses/by/3.0/). 